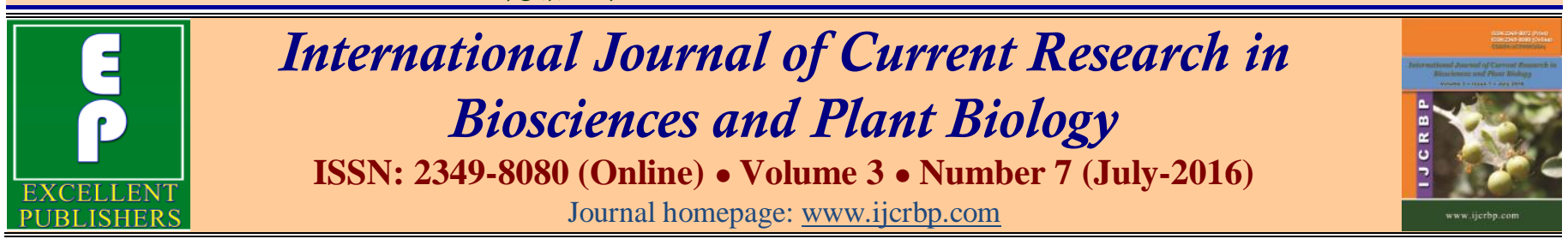

Review Article

doi: http://dx.doi.org/10.20546/ijcrbp.2016.307.017

\title{
Vacuum Impregnation: A Novel Non-thermal Technique to Improve Food Quality
}

\author{
Pratibha Tiwari* and Monika Thakur \\ Amity Institute of Food Technology, Amity University, Noida-201 303, Uttar Pradesh, India \\ *Corresponding author.
}

\begin{abstract}
Vacuum impregnation (VI) is a non-thermal, non-destructive treatment that aims to modify the composition of food material by partially removing water and impregnating it with physiologically active compounds without affecting the material's structural integrity. Vacuum impregnation can be used to accelerate the Industrial process. It has various advantages like fast process, energy economical and easily performed at room temperature. VI basically fills large volume of intercellular spaces in tissues of fruits and vegetable and modifies the physico-chemical and the organoleptic properties of the same. Furthermore, providing enough information on the various advantages of these techniques is yet to be explored and is underutilized. Present review explores the importance and technique of VI with the future gaps so that the same technology can be further exploited commercially.
\end{abstract}

Article Info

Accepted: 01 July 2016

Available Online: 06 July 2016

Keywords

Deformation relaxation phenomenon Hydrodynamic mechanism Osmotic dehydration

Physiologically active compound Response surface methodology Vacuum impregnation

\section{Introduction}

Increased consumer interests in the foods that provide Biological active compounds and health benefits have led to significant development of nutraceuticals and functional foods (Zhao and Xie, 2004). Mazza (1998) discussed the health benefits as one of the specific issues that will greatly influence the food industry in the coming years and will be more focused on the same. Menrad et al. (2000) stated that the expectations have been on the rise from various market players for food products that meet consumer demands for a healthy and active lifestyle. The need of healthy and active lifestyle has brought into notice the concept of Functional foods. Functional foods are defined as those physiologically active compounds (PAC) that provide an additional physiological benefits that in turn prevent disease or promote health and well being (Stauffer, 1999).

Functional foods provide various health benefits, and have various bioactive components as antioxidants, phytochemicals, dietary fibres, herbs and botanicals, probiotics, prebiotics, synbiotics, etc. (Alzamora et al., 2005; Lakhanpal and Rana, 2015). In the present scenario many modified techniques have been developed to add these bioactive components (BAC) into the foods by various processes so that the food will have high health promoting values and at the same time that is being characterized by desirable sensory attributes. Vacuum Impregnation is one of the recent and modified techniques to fulfil the desirable requirements of the well aware consumers.

lgual et al. (2008) discussed VI as a new processing technique based on the process of diffusion. Recently, the interest in the application of vacuum impregnation techniques has exponentially increased because of its major role in the improvement of food quality. It has been basically a method in food processing by which most air and part or all of the native solution are removed 
from the food porous spaces (vacuum) and replaced by an external solution (impregnation) (Fito, 1994; Laurindo et al., 2007). It is based on the application of a partial vacuum pressure which allows to remove native liquids and gases entrapped into the capillaries and to impregnate them with a desired external solution after the restoration of atmospheric pressure. At first, a Vacuum Osmotic Dehydration (VOD) treatment was proposed and studied as method to accelerate the water loss and solid gain during the immersion of vegetables into various hypertonic solution. Now, VI treatments have been studied as new innovative method to enrich food not only with nutritional and functional components but also with the aim to obtain food with innovative sensorial properties as well as to able to inhibit the most important degradation reactions and the microbial growth (Deroosi et al., 2010). Sometimes, VI has also been used as pre-treatment before drying or freezing as it improves the quality of final product and reducing cost operations due to the removal of native liquid (water) from the pores (Zhao and Xie, 2004). Thus, the present study aims to review the application and importance of Vacuum Impregnation technique in food industry so that the unexplored potential can be fully exploited.

\section{Importance of vacuum impregnation}

At present, methods are being searched to provide food with high health - promoting value, at the same time characterized by sensory attributes. VI has been a recently developed food processing technique based on diffusion (Elzbieta et al., 2014). VI has been used for the incorporation of physiologically active components (PAC) into the structure of food products especially fruit and vegetables (Fito et al., 2001). Osmotic treatment (OT) is considered to be a feasible technology for developing fruit and vegetable matrices to which functional ingredients can be successfully added to provide novel functional product categories and new commercial opportunities (Alzamora et al., 2005). OT is a non- thermal treatment, aiming to modify the composition of food material by partially removing water and impregnating it with solutes, without affecting the material's structural integrity (Spiess and Behsnilian, 1998).

It has dual advantages, firstly it will partially dehydrate the sample; and secondly it enables to introduce controlled quantities of solute into the food particles. The quality can be improved not only by removing water with the minimal thermal stress but also by impregnating the solutes and modifying the structure (Torreggiani and
Bertolo, 2001). Very Often, Osmotic Dehydration (OD) is confused with Vacuum Impregnation (VI) since OD and VI both, belongs to the Osmotic treatment technique but there are differences between the two. OD is a process that partially removes water from food material by means of food immersion in a hypertonic solution (i.e. sugar and salt). It is a counter-current mass transfer process, in which water is drained from the interior of the food to the hypertonic solution and the solute flows into the food. VI on the other hand, is a food fortification process that has been characterised by the mass transfer between an external impregnation solution and the food matrix as a result of the exposure to vacuum (Bhattacharya, 2014).

Chiralt et al. (1999) and Fito et al. (2001) observed that salting process, osmotic dehydration and other solidliquid operations can be improved by applying vacuum pressures to the system, with a significant decrease in the processing time, depending on the product porosity and mechanical properties. From these findings it has been cleared that VI and OD both have been non-thermal OT but the VI has been a novel technique in comparison to OD. Reason being, the osmotic dehydration is not rapid enough and should be improved with the further permeabilization of cell membranes and by reducing the water activity of foods so that microbial growth can effectively be inhibited. The damage of membranes can be achieved by blanching or non-thermal pre-treatments, such as the application of high pressure, ultra-sound or a pulsed electric field and also can be achieved applying gamma-irradiation, vacuum or centrifugal force during osmotic dehydration (Rastogi et al., 2005; Amami et al., 2005). There are various other differences between the two techniques described in Table 1 .

VI and OD differ in the mechanism to undergo the process as well. This difference in mechanism of action has been described below:

\section{Mechanism of VI}

VI and OD as an osmotic treatment, result in food fortification. Fortification of food products aims to prevent various deficiencies of nutrients like vitamins, minerals or other addition of health promoting substances. It can be successfully done with the modification of physicochemical properties of particular active ingredient, the interaction between ingredients and additive and food matrix, the uptake, translocation properties, bioavailability, stability as well as sensory aspects like taste and colour changes (Bhattacharya, 2014). 
Table 1. Difference between OD and VI (Elzbieta et al., 2014).

\section{Osmotic dehydration ( OD)}

Mass transfer is based on the difference in concentration between the intercellular liquid in the food material and the solution.

The main effect is partial water removal from the material, which moves in the direction of concentration gradient.

Osmotic Dehydration requires the use of hypertonic solutions and the process takes place at atmospheric pressure.

Long duration process.

Possible leaching of nutrients from tissues.

The most common compounds of osmotic solution- salt or sugar change the taste significantly and decrease the nutritional value of food.

External solution can be used single time only.

\section{Vacuum impregnation (VI)}

Mass transfer occurs as a result of mechanically induced difference in pressures.

In this method the injection of the external solution into the material has been the main goal.

Since the application of vacuum is the only necessity, hence the solution may be isotonic.

Fast process (get completed in few minutes) and needs low energy cost.

No leaching of nutrients.

No such change in taste and decrease in nutritional value have been observed.

External solutions may be reused many times and it can be performed at low temperature.
VI and OD basically alter the food composition through the following described different mechanisms:

The method is based on the application of two steps (Zhao and Xie, 2004; Chiralt et al., 1999; Fito et al., 2001; Derossi et al., 2010).

(i) The immersion of food inside aqueous solution and the application of a vacuum pressure for a time $\mathrm{t}_{1}$ (Vacuum period): in this step, the internal gas in the product pores of the product has been expanded and partially flows out. All this is coupled with the capillary penetration as a interfacial tension of the liquid and the diameter of the pores.

(ii) The restoration of the atmospheric pressure keeping the food products immersed in aqueous solution for time $t_{2}$ (relaxation time/ atmospheric period) : during this step, the residual gas is compressed, and the external liquid flows into the pores as a function of the compression ratio.

Fig. 1 schematically shows the phenomena involved during vacuum solid-liquid operations of an ideal pore. Deformation - Relaxation phenomena and hydrodynamic mechanism occurring during vacuum period $\left(\mathrm{t}_{1}\right)$ and relaxation time $\left(\mathrm{t}_{2}\right)$ (Fito et al., 1996).

Step 1. At time zero the samples are immersed into the external liquid and the internal pressure of the pore (pi) is equal to external (atmospheric) pressure (pe). 1(a) After, a vacuum pressure (p) is applied in the head space of the system foe a time $\left(t_{1}\right)$ promoting a situation in which pi is greater than pc.
In this condition, the internal gases expand producing the deformation (enlargement) of capillary and the increase of internal volume. Moreover, native liquids and gases partially flow out on the basis of the pressure gradient (step1-A).

1(b) At this time hydrodynamic mechanism begins and the external liquid partially flows inside the capillary as a consequence of the pressure gradient. These phenomena simultaneously occur until the equilibrium is reached (Step 1-B).

Step 2. In the second step the atmospheric pressure in the head space of the system is restored and the samples are maintained into the solution for a relaxation time $\left(t_{2}\right)$.

During this period, the generated pressure gradient (pi is smaller than pe) promotes both HDM and solid matrix deformation (compression) which respectively produce capillary impregnation and the reduction of pore volume until a new equilibrium is reached (Fito and Chiralt, 1994; Fito et al., 1996).

During VI process in addition to HDM, a deformationrelaxation phenomena (DRP) simultaneously occurs. HDM and DRP both affect the reaching of an equilibrium situation and their intensities are strictly related with the three dimensional food microstructure and mechanical properties of solid matrix.

There are various parameters which is to be identifying in order to get the food fortified. Fig. 2 describes sodium system parameters, which are responsible for the circumstances of treatment. The product characteristics 
contain the material properties and quality changes by potential upstreaming processes. Thirdly and lastly, the solution composition is listed. With such tools in hand, scientist and food technologist may be able to modify and control the process of OD and VI to modulate food for specific industries and consumer demands.

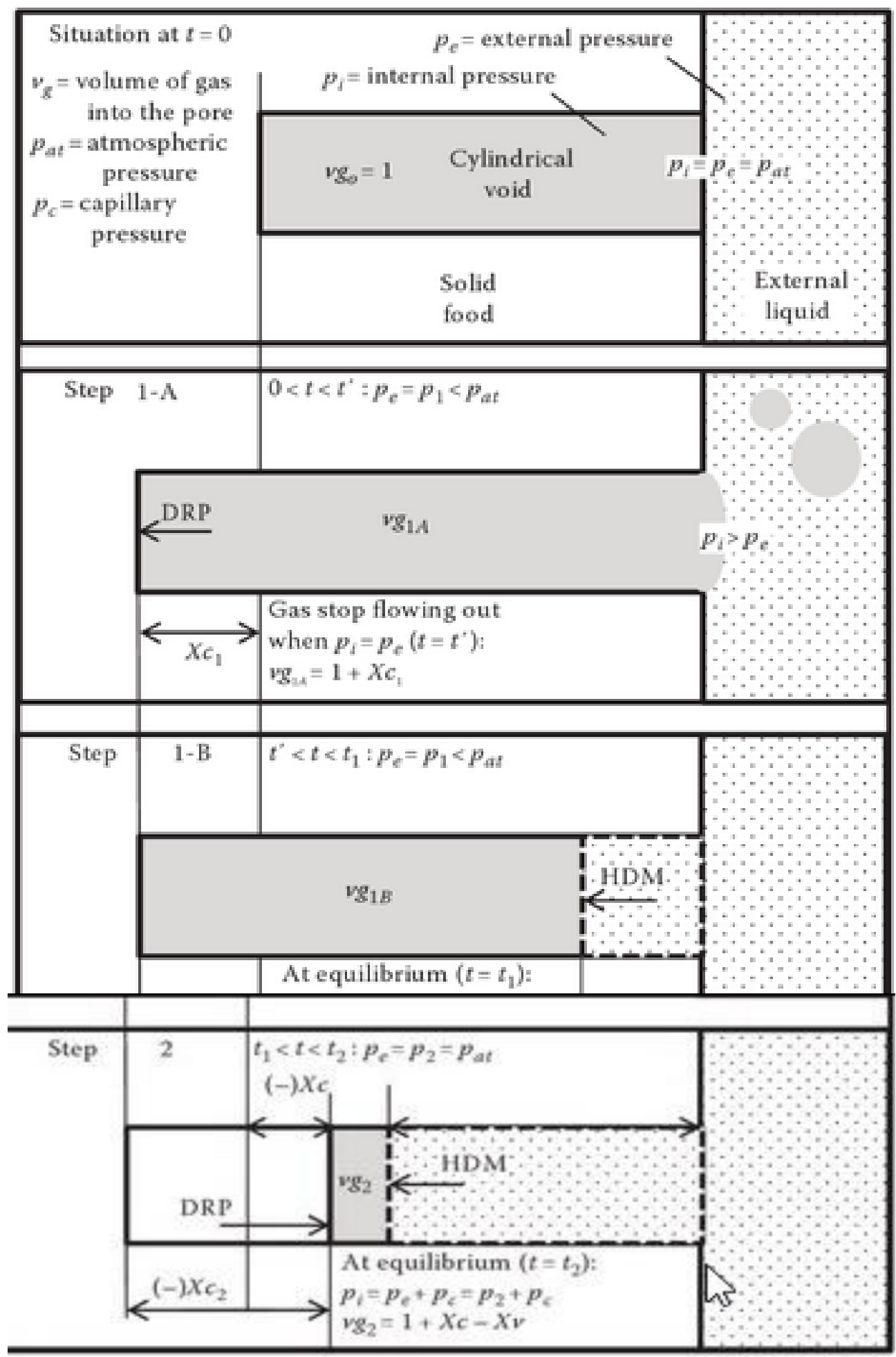

Fig. 1: Vacuum impregnation of an ideal pore (Fito et al., 1996). DRP, Deformation- Relaxation Phenomena and HDM, Hydrodynamic Mechanism. 


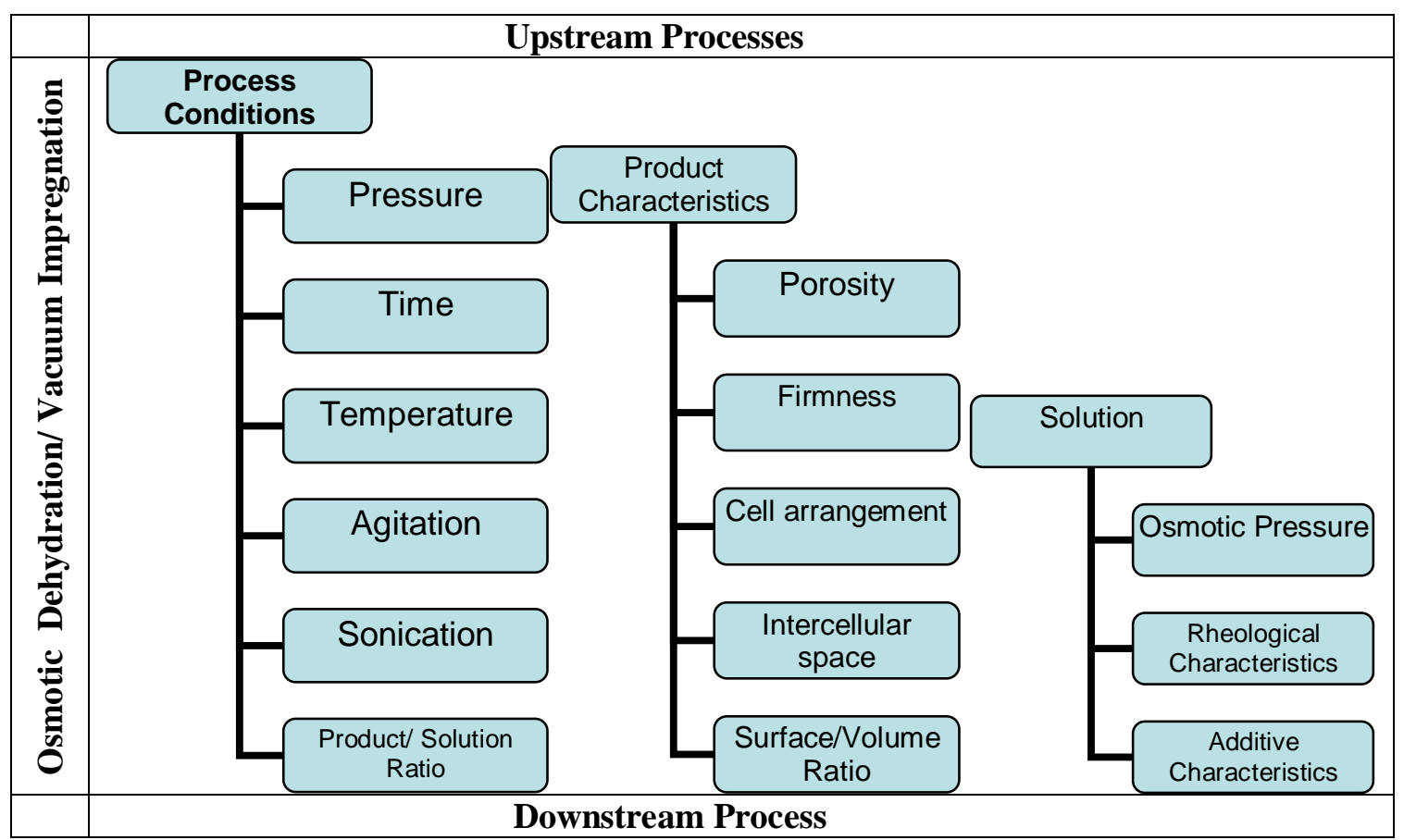

Fig. 2: Influence parameters on food modification by VI and OD; Overview of process management factors to control the food composition by osmotic dehydration or vacuum impregnation applications.

\section{Food modification by VI}

Various studies have been focused on the effect of the VI treatment conditions on the deformation of samples (Martínez-Monzó et al., 1998, Cháfer et al., 2003). Thus the main changes induced by osmotic treatment which affect the mechanical behaviour of plant tissues as: loss of cell turgor; cell debonding; alterations in cell wall resistance; density of cell packaging, sample size and shape; temperature (Vincent, 1994; Pitt, 1992), changes in water and solute concentration profiles (Salvatori et al., 1998), and changes in air and liquid volumetric fraction in the sample (Fito, 1994) (Fig. 3).

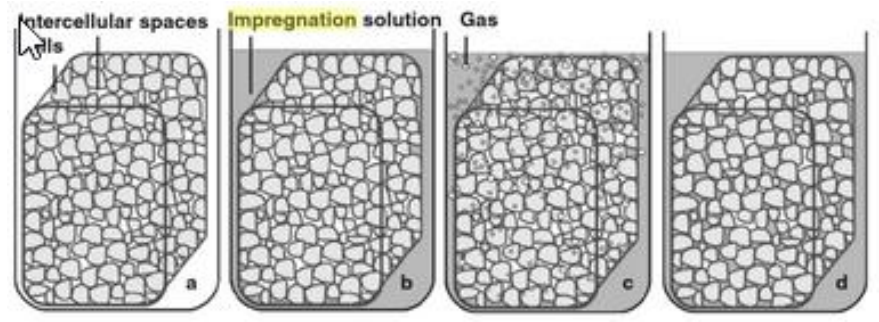

Fig. 3: Schematic representation of liquid and gas exchange steps during the vacuum impregnation process of a porous cell complex (a) Native plant tissue; (b) Plant tissue soaked im impregnation solution under atmospheric pressure conditions; (c) Gas release from intercellular spaces during the vacuum phase (d) Vacuum impregnated plant tissue soaked in impregnation solution after restoring the atmospheric pressure conditions.
Zhao and Xie (2004) reported that VI has been helpful in determining the qualities of finished products by processing conditions such as vacuum time and restoration time. However, on the basis of its nature, VI has been a very complex treatment and its results are effected from several internal and external variables (Gras et al., 2003; Zhao and Xie, 2004; Fito, 1996) Internal factors include properties of the impregnated tissue, such as its structure (porosity), mechanical properties, the shape and size of the capillary as well as the shape and the size of the sample. External factors influencing the rate of impregnation include the level of applied vacuum pressure, the composition and concentration of the impregnating solution, temperature, the of the solution amount to product ratio, mixing, the time required to reach vacuum and the duration of vacuum treatment as well as the restoration of atmospheric pressure. Besides having the effect of internal and external factors on VI operations, there are various applications of VI through which qualities of finished products can be improved and these applications and the final product will be of better quality.

\section{Application of VI}

VI contributes to add quality, connected with physicochemical properties and sensory attributes. When HDM was proposed as an additional mass transfer mechanism occurring during osmotic dehydration, the first 
application of VI techniques had the aim to increase the rate of osmotic dehydration through the impregnation of capillaries with hypertonic solutions. Since then, vacuum osmotic dehydration (VOD) was subject to a great number of scientific papers; in addition to VOD, the application of an initial vacuum pulse followed by the restoration of atmospheric pressure and the maintaining of food immersed into the osmotic solution for a long time was proposed as pulsed vacuum dehydration (PVOD) (Derossi et al., 2010). In general it is possible to consider two principle aims: (i) the increase of mass transfer; (ii) The introduction of chemical and biological compounds in food microstructure with the aim to improve their quality. On this basis, VI may be used as pre-treatment before drying or freezing, as innovative treatment inserted into a more complex processing with several industrial applications. Vacuum impregnation (VI) has been recognised as a useful method to improve the rate of several infusion treatments (Zhao and Xie, 2004).
Although the VI technique was proposed as method to improve the rate of osmotic dehydration (Paes et al., 2007; Fito et al., 2001a, b) several innovative applications have been recently studied. Application of VI process using fruit juices and sugar syrups containing minerals, vitamins, bioactives and other food ingredients is an excellent way of producing fortified or value- added fruit products (Betoret et al., 2003; Xie and Zhao, 2003). VI can also be used to modify the compositional, thermal and physico-chemical properties of food products which will increase the process efficiency in a manner beneficial for attaining desired product characteristics such as improved taste, texture, and shelf life (Anino et al., 2006) and Fito et al., 2001). Thus, it is essential to determine the potential of this technique to modify physico- chemical characteristics and sensory attributes of products, as well as to select appropriate parameters to ensure the desired effect (Zhao and Xie, 2004a). Examples of application of VI in food industry have been listed in Table 2 .

Table 2. Examples of application of Vacuum Impregnation in food industry.

\begin{tabular}{|c|c|c|c|}
\hline Raw material & $\begin{array}{l}\text { Solution used for vacuum } \\
\text { impregnation }\end{array}$ & Effect & References \\
\hline Whole Potatoes & $\begin{array}{l}\text { Zinc gluconate solution }(9 \mathrm{~g} / 100 \mathrm{~g} \\
\text { zinc) }\end{array}$ & $\begin{array}{l}\text { Zinc content of VI potatoes (peeled or } \\
\text { unpeeled)increased with vacuum and } \\
\text { restoration time ( } 69-70 \text { times). }\end{array}$ & Erihemu et al. (2015) \\
\hline Whole Potatoes & Ascorbic acid solution (10\%) & $\begin{array}{l}\text { VI whole potatoes had a relatively high } \\
\text { ascorbic acid concentration }(50 \mathrm{mg} / 100 \mathrm{~g} \\
\text { fr.wt.) }\end{array}$ & Hironika et al. (2011) \\
\hline $\begin{array}{l}\text { Apple slices (cut into } \\
2 \mathrm{~mm} \text { thick slices) }\end{array}$ & $\begin{array}{l}\text { Grape juice with the addition of } \\
\text { response surface methodology }\end{array}$ & $\begin{array}{l}\text { Multiple response optimization revealed } \\
\text { the following optimum VI conditions for } \\
\text { the bioactive enrichment and improved } \\
\text { textural quality of dried apple slices. }\end{array}$ & $\begin{array}{l}\text { Joshi and Handunkutti } \\
\text { (2010) }\end{array}$ \\
\hline Truffles & Anti-freezing solution & $\begin{array}{l}\text { Degradation of consistency probably } \\
\text { caused by ice crystal formation } \\
\text { commonly observed in freeze thawed } \\
\text { truffles get reduced thereby preserving } \\
\text { the texture of truffles stored in frozen } \\
\text { conditions. }\end{array}$ & Derossi et al. (2015) \\
\hline Wheat Grain & Various Gluten concentration & $\begin{array}{l}\text { Significant difference of morphological } \\
\text { structure were observed resulting in } \\
\text { acceleration of the long term process of } \\
\text { wheat preparation to many production } \\
\text { processes (e.g. milling of flour, hulling, } \\
\text { etc.) }\end{array}$ & $\begin{array}{l}\text { Leszek and Dariusz } \\
(2008)\end{array}$ \\
\hline Apple Sticks & $\begin{array}{l}\text { Mass ratio of fruit syrup was } \\
1: 17 \text {, fructose isotonic solution } \\
\left(14.0^{0}-15^{0} \text { Brix containing }\right. \\
\text { ascorbic acid }\left(0.5 \% \mathrm{w}_{1} / \mathrm{w}_{1}\right) \text { and } \\
\text { dry, food grade green apple } \\
\text { flavouring }\left(0.5 \% \mathrm{w}_{1} / \mathrm{w}_{1}\right) .\end{array}$ & $\begin{array}{l}\text { Relative amount of the major } \\
\text { compounds of impregnation flavouring } \\
\text { were recorded, aroma enrichment. }\end{array}$ & $\begin{array}{l}\text { Comandini et al. } \\
\text { (2010) }\end{array}$ \\
\hline $\begin{array}{l}\text { Papayas (cut into } 4 \mathrm{x} \\
2.5 \mathrm{x} 0.5 \mathrm{~cm}) \text { pieces, } \\
\text { Strawberry }\end{array}$ & $\begin{array}{l}55 \% \text { and } 65 \%(\mathrm{w} / \mathrm{w}) \text { sucrose } \\
\text { solution, } 65 \%(\mathrm{w} / \mathrm{w}) \text { sucrose } \\
\text { solution }\end{array}$ & Decrease of water activity. & $\begin{array}{l}\text { Moreno et al. (2004) } \\
\text { Moreno et al. (2000) }\end{array}$ \\
\hline
\end{tabular}




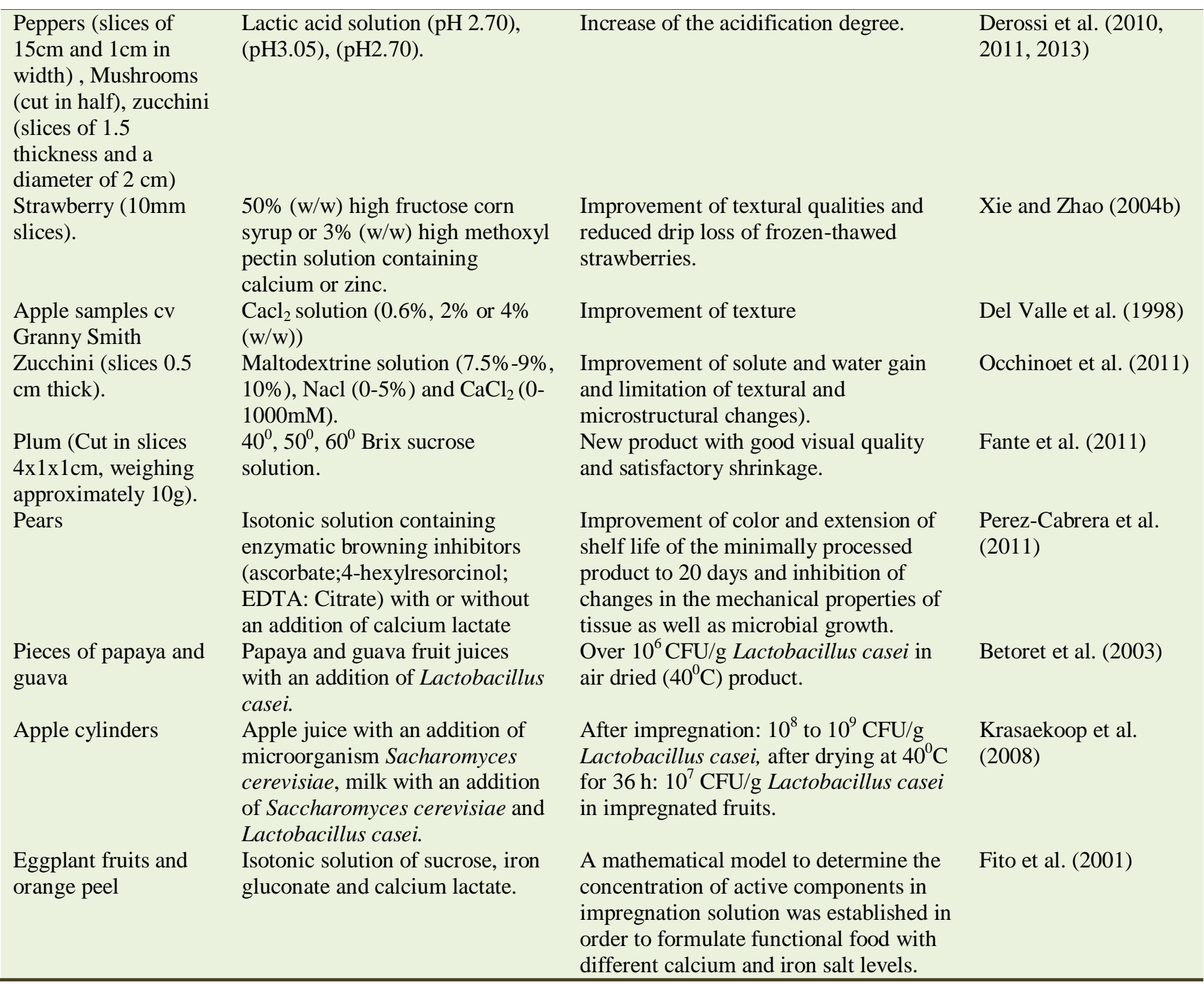

\section{Miscellaneous applications}

VI treatment has also been used in various miscellaneous applications as: effective in preventing discoloration of fruit pieces by enzymatic and oxidative browning, without using antioxidant, via removal of oxygen from the pores (Alzamora et al., 2000; Barbosa-Canovas and Vega-Mercado, 1996).

\section{Future gaps}

Although vacuum impregnation was for the first time proposed at least 20 years ago, it may be still considered an emerging technology with very high potential applications. Due to its unique characteristics, it has been the first food processing technique based on the exploitation of three dimensional food microstructure.
Mebatsion et al. (2008) used the term "microscopic" classification for the study of fruit microstructure. They considered three different spatial scales (Mesoscale, Microscale and Mesoscopic) as shown in Fig. 4.

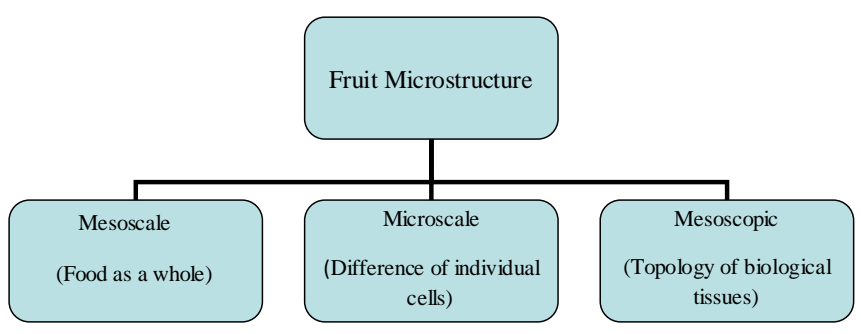

Fig. 4: Microscopic classification of fruit.

So, one of the most important future challenge will be the precise characterization of the three dimensional architecture of foods, its changes during food processing 
and its relation with safety and quality (Datta, 2007a; Datta, 2007b; Halder et al., 2007). The term "Food matrix engineering (FME)" has been used to define a branch of food engineering that applies the knowledge about food matrix composition, structure and properties with the aim to promote and control adequate changes that improve some sensorial /functional properties in the food products as well as their stability (Fito et al., 2003). Also the lack of information for industries on the advantages of these techniques may be the reason for its reduced applicability at industrial level.

Another challenge involves the lack of industrial plants in which it has been possible to precise control the operative conditions during the two steps of the process. Zhao and Xie (2004) reported the complete immersion of foods into the external solution is a challenge for the correct application of VI as low density fruits and vegetables tend to float with external solution (osmotic solution). Keeping this in view, now VI is applied by stirring solution with the aim to keep food pieces inside solution with the drawback of an increase of energy costs and possible damages of foods. Furthermore, information should be made available on the applications and advantages of these techniques, thereby increasing its application at industrial scale.

\section{Conclusions}

In today's scenario, various innovative methods have been searched by food processing sector to modify the functional properties of food. Plant tissue is a perfect matrix, which could be a carrier of bioactive components and nutrients. At the same it is important to ensure that such foods have preferred sensory attributes and storage stability. More recently, VI treatments has been studied as methods to enrich food with nutritional and functional compounds, to introduce some ingredients with the aim to obtain food with innovative sensorial properties as well as to introduce compounds able to inhibit the most important degradation reactions and the microbial growth. VI is the method in food processing by which most air and part or all of the native solution are removed from the food porous space (vacuum) and replaced by an external solution (impregnation). VI has shown to be very effective in a wide number of industrial applications. VI may be used as pre-treatment before drying or freezing, improving the quality of final product and reducing cost operation due to removal of native liquid (water) from the pores. Furthermore, from an engineering point of view VI has various advantages like it is a fast process, it needs low energy costs, it is performed at room temperature, and the external solution may be reused many times. Although VI was for first time proposed few years ago, it has been still considered an emerging technology with high potential applications because industrial scale application is yet very poor. Therefore, the present reviews aims to throw light on the importance of VI in food processing and how it improves the quality of food products. Thus, this unexplored technique can further be fully explored and exploited for the quality of food.

\section{Conflict of interest statement}

Authors declare that they have no conflict of interest.

\section{Acknowledgement}

The authors gratefully acknowledge the support provided by Dr. A.S. Bawa, Director Amity Institute of Food Technology, Amity University, Noida and Dr. Alka Joshi, Scientist (ARS), Division of Food Science and Postharvest Technology (FS \& PHT), ICAR-Indian Agricultural Research Institute (IARI), New Delhi, India.

\section{References}

Ajit, P., Joshi, K., Handunkutti, P., Vasantha, R., 2010. Optimization of bioactive fortification in apple snacks through vacuum impregnation using response surface methodology. Food Nutr. Sci. 2, 45-52.

Alzamora, S. M., Salvatori, D., Tapia, M.S., Lopez- Malo, A., Welti- Chanes. J., Fito, P., 2005. Novel functional foods from vegetable matrices impregnated with biologically active compounds. J. Food Eng. 67, 205-214.

Alzamora, S.M., Tapia, M.S., Leunda, A., Guerrero, S.N., Rojas, A.M., Gerschenson, L. N., 2000. Minimal preservation of fruits: A cited project. In: Trends in Food Engineering (Eds.: Lozano, J.E., Anon, C. E., Parada, A., Barbosa-Canovas, G.V.). Technomic Publishing, Pennsylvania, USA. pp.205-225.

Amami, E., Vorobiev, E., Kechaou, N., 2005. Effect of pulsed electric field on the osmotic dehydration and mass transfer kinetics of apple tissue. Dry Tech. 23(3), 581-595.

Andreas, I., Salvatori, D., Chiralt, A., Fito, P., 2001.Vacuum impregnation viability of some fruits and vegetables. In: Osmotic Dehydration and Vacuum Impregnation: Application in Food Industries, $1^{\text {st }}$ Edn. (Eds.: Fito, P., Chiralt, A., Barat, J.M., Spiess, W.E.L., Behsnilian, D., Barat, J.M., Spiess, W.E.L., Behsnilian, D.). Technomic Publishers, Lancaster, USA.

Anino, S. V., Salvatori, D.M., Alzamora, S.M., 2006. Changes in calcium level and mechanical properties of apple tissue due to impregnation with calcium salts. Food Res. Intern. 
39, 297-302.

Barbosa-Canovas, G.V., Vega-Mercado., H., 1996. Osmotic dehydration of foods. International Thomson, Florence, Italy. pp.265-288.

Betoret, N., Puente, L., Diaz, M.Z., Pagan, Garcia, M.J., Gras, M.L., Martinez-Monzo, J., Fito, P., 2003. Development of probiotic-enriched dried fruits by vacuum impregnation. J. Food Eng. 56(2), 273-277.

Bland, G., Cerretani, L., Bendin, A., Cardinal, A., Scarpellin, A., Lercker, G., 2008. Effect of vacuum impregnation on the phenolic content of Granny Smith and Stark Delicious frozen apple cvv. Eur. Food Res. Technol. 226, 12291237.

Chiralt, A., Fito P., Andres, A., Barat, J., 1999. Vacuum impregnation: A tool in minimally processing of foods. Processing of Foods Quality, Optimization and Process Assessment. pp.341-356.

Commandini, P., Blanda, G., Paz, H.M., Fragoso, A. V., Toschi, T. G., 2010. Impregnation techniques for aroma enrichment of apple sticks: A preliminary study. Food Bioproc. Technol. 3(6), 861-866.

Datta, A.K., 2007a. Porous media approaches to studying simultaneous heat and mass transfer in food processes. I: Problem formulations. J. Food Eng. 80, 80-95.

Datta, A.K., 2007b. Porous media approaches to studying simultaneous heat and mass transfer in food processes. $2^{\text {nd. }}$ : Property data and representative results. J. Food Eng. 80, 96-110.

Del Valle, J.M, Aranguiz, V., León, H., 1998. Effects of blanching and calcium infiltration on PPO activity, texture, microstructure and kinetics of osmotic dehydration of apple tissue. Food Res. Int. 31, 557-569.

Derossi, A., De, Pilli, T., Severini, C., 2010 Reduction in the $\mathrm{pH}$ of vegetables by vacuum impregnation: a study on pepper. J. Food Eng. 99, 9-15.

Derossi, A., Iliceto, T., De Pilli, C. Severini. 2015. Application of vacuum impregnation with anti-freezing proteins to improve the quality of truffles. J. Food Sci. Technol. 52(11), 7200-7208.

Elzbieta, R.K., Roza, B.M., Mercin, K., 2014. Applicability of vacuum impregnation to modify physico-chemical, sensory and nutritive characteristics of plant origin products- A review. Int. J. Mol. Sci. 15, 16577-16610.

Erihemu., Hironiaka, K., Koaze, H., Oda, Y., Shimada, K., 2015. Zinc enrichment of whole potato tuber by vacuum impregnation. J. Food Sci. Technol. 52, 2352-2358.

Fante, C., Corrêa, J., Natividade, M., Lima, J., Lima, L., 2011. Drying of plums (Prunus sp., cv. Gulfblaze) treated with $\mathrm{KCl}$ in the field and subjected to pulsed vacuum osmotic dehydration. Int. J. Food Sci. Technol. 46, 1080-1085.

Fito, P., Andres, A., Chiralt, A., Pardo, P., 1996. Coupling of hydrodynamic mechanisms and deformation- relaxation phenomena during vacuum treatments in solid porous food-liquid systems. J. Food Eng. 27(3), 229-241.

Fito, P., Chiralt, A., Betoret, N., Gras, M., 2001. Vacuum impregnation and osmotic dehydration in matrix engineering. Application in functional fresh food development. J. Food Eng. 49, 175-183.

Fito, P., Chiralt, A., Betoret, N., Gras, M., Chafer, M., Martinez- Monzo, J., Andres, A., Vidal, D., 2001 a. Vacuum impregnation and osmotic dehydration in matrix engineering application in functional fresh food development. J. Food Eng. 49, 175-183.

Fito, P., Chiralt, A., Barat, J.M., Gonalez- Martinez, A. C., Andres, J., Martinez Monzo, Martinez- Navarette, N., 2001. Vacuum impregnation for development of new dehydrated products. J. Food Eng. 49(4), 297-302.

Fito, P., Chiralt, A., 1994. An update on vacuum osmotic dehydration. In: Food Preservation by Moisture Control: Fundamentals and Application. Technomic Publishers, Lancaster, PA. pp. 351-372.

Fito, P., 1994. Modelling of vacuum osmotic dehydration of food. J. Food Eng. 23, 313-328.

Halder, A., Dhall, A., Datta, A.K., 2007. An improved, easily implementable porous media based model for deep-fat frying Part 1: Model development and input parameters. Food Bioprod. Process. 85, 209-219.

Hironika, K., Kikuchi, M., Koaze, H., Sato, T., Kojima, M., Yamamoto, K., Yasuda, K., Mori, M., Tsuda, S., 2011. Ascorbic acid enrichment of whole potato tuber by vacuum - impregnation. Food Chem. 127, 1114-1118.

Krasaekoopt, W., Suthanwong, B., 2008. Vacuum impregnation of probiotics in fruit pieces and their survival during refrigerated storage. Kasetsart J. 42, 723731.

Lakhanpal, T. N., Rana, M., 2005. Medicinal and nutraceutical genetic resources of mushrooms. Plant Genetic Res.: C. 3, 288-303.

Laurindo, J. B., Stringari, G., Paes, S., Carciofi, B. A. M., 2007. Experimental determination of the dynamics of vacuum impregnation of apples. J. Food Sci. 72, E470E475.

Leszek, R., Andrezko, D., 2008. Vacuum impregnation process as a method used to prepare the wheat grain for milling in flour production. TEKA Kom. Mot. Energ. Roln. - OL PAN, 8a, 134-141.

Lgual, M., Castello, M.L., Ortola, M.D., Andres, A., 2008 Influence of vacuum impregnation on respiration rate, mechanical and optical properties of cut permission. J. Food Eng. 86, 315-323.

Mazza, G., 1998. Functional Foods: Biochemical and Processing Aspects. Technomic Pub. Co., Lancaster.

Mebatson, H.K., Verboven, P., Ho, Q.T., Verlinden, B.E., Nicolai, B.M., 2008. Modelling fruit (micro) structures, why and how. Trends Food Sci. Technol. 19, 59-66

Menard, M., Husing, B., Menard, K., Rei, T., Beer-Borst, S., Zenger, C. A., 2000. Functional Food. TA 37/2000.

Moreno, J., Bugueno, G., Velasco, V., Petzold, G., TabiloMunizaga, G., 2004. Osmotic dehydration and vaccum impregnation or physicochemical properties of Chilean papaya (Carica candamarcensis). J. Food Sci. 69(3), 102106.

Occhino, E., Hernando, I., Liorca, E., Neri, L., Pittia, P., 2011. Effect of vacuum impregnation treatments to improve 
quality and texture of zucchini (Cucurbita pepo L.). Procedia. Food Sci. 1, 829-835

Perez-Cabrera, L., Chafer, M., Chiralt, A., GonzalezMartinez, C., 2011.effectiveness of antibrowning agents applied by vacuum impregnation on minimally processed pear. LWT Food Sci. Technol. 44, 2273-2280.

Rastogi, N.K., Raghavarao, K.S.M.S., Niranjan, K., 2005. Developments in osmotic dehydration. In: Emerging Technologies for Food Processing (Ed.: Sun, D.W.). Elsevier-Academic Press, Italy.

Sindawal, S., Bhattacharya, S., 2014. Fortification and impregnation practices. Conven. Adv. Food Process. Technol. 3, 338.

Spiess, W. E. L., Behsnilian, D., 1998. Osmotic treatments in food processing. Current stage and future needs. In: Drying '98' A, Ziti Editions, Greece. Pp.47-56.

Stauffer, J.E., 1999. Neutraceuticals. Cereals Foods World. 44,
115-117.

Torreggiani, D., Bertolo, G., 2001. Osmotic pre-treatments in fruit processing: chemical, physical and structural effects. J. Food Eng. 49(2-3), 247-253.

Xie, J., Zhao, Y., 2004a. Practice application of vacuum impregnation technology in fruit and vegetable processing. Trends Food Sci. Technol. 15(9), 434451.

Xie, J., Zhao, Y., 2004b. Use of vacuum impregnation to develop high quality and nutritionally fortified frozen strawberries. J. Food Process. Preserv. 28, 117-132.

Xie, J., Zhao, Y., 2003. Nutritional enrichment of fresh apple (Royal Gala) by vacuum impregnation. Int. J. Food Sci. Nutr. 54, 387.

Zhao, Y., Xie, J., 2004. Practical application of vacuum impregnation in fruit and vegetable processing. Trends Food Sci. Technol. 15, 434-451.

\section{How to cite this article:}

Tiwari, P., Thakur, M., 2016. Vacuum impregnation: A novel non-thermal technique to improve food quality. Int. J. Curr. Res. Biosci. Plant Biol. 3(7), 117-126. doi: http://dx.doi.org/10.20546/ijcrbp.2016.307.017 